\title{
Causes of Students Drop out in General Education in The Directorate of Education Schools in Karak Governorate from The Point of View of School
}

\author{
Yousef Diab Al-Majali ${ }^{1} \&$ Mohammad Abd alrahman AL-Thneibat ${ }^{1, *}$ \\ ${ }^{1}$ Department of Educational Sciences, Balqa Applied University, Al-Salt, Jordan \\ *Corresponding author: Department of Educational Sciences, Balqa Applied University, Al- \\ Salt, Jordan.E-mail: abuwesssam73@yahoo.com
}

Received: February 18, 2013 Accepted: April 11, 2013 Published: June 24, 2013

doi:10.5296/ije.v5i2.3275ＵRL: http://dx.doi.org/10.5296/ije.v5i2.3275

\begin{abstract}
The study aims to identify the relative importance of each paragraph of the reasons paragraph for dropping out of school, and for each of the reasons for dropping out of school from the viewpoint of school principals and teachers in school districts in the governorate of Al Karak, and identify the moral differences between the average degrees of reasons for dropping out of school from the viewpoint of principals and teachers. The sample of the study consisted of (298) principals and teachers (male and female), of whom (69) principals, (229) teachers. The researchers used questionnaire to identify the reasons for dropping out of school; using the degree of intensity, percentages, and analysis of variance. The results of the study showed that the main paragraph for dropping out of school from the perspective of principals, respectively is: (lack of the learner friends of education). The results of the study showed that the main paragraph for dropping out of school from the perspective of teachers, respectively is: (learner having a physical handicapped that provoke the mockery of his colleagues). The result of the study also shows that the main reason for school dropout from the view point of principles is: bad companionship with directly followed by family. Learner school .The results of the study also showed that the major reasons for dropping out of school from the viewpoint of teachers, respectively, are: bad companionship respectively followed by learner, family, school. The study also showed that there were no statically differences between average degrees of reasons for dropping out of school from the viewpoint of principles and teachers in school districts in the governorate of Al Karak.
\end{abstract}

Keywords: school dropout; the directorates of education; governorate 


\section{Introduction}

Despite the growing interest of Governments and education in recent years as the main road to progress and overall development of the individual and community, and this interest is reflected in the adoption of the principle of equal educational opportunities, applying the policy of compulsory and free education, providing the material and human potential and to achieve it by buildings school e and equipping them with tools, books, teachers and different educational materials for teachers, we still suffer from many education problems with its negative repercussions on the individual, the family the community and the educational system as a whole, and drop out is one of the most serious of these problems.

The subject of school dropout is one of the important educational and social matters. dropout risk increased in the initial stages of learning and it is more dangerous and harmful than it is in later stages, and dropout is one of the manifestations of the wastage of the educational system, which refers to the difference between the numbers of students enrolled in some stage of education and the number of graduate students at the end of the stage. The number of dropout pupils in developed countries is less than it is in developing and poor countries, and often the dropout number within the same country increase rural, Bedouin and remote areas than in urban areas, and it increases among girls in particular communities that deny them the right to continue their education or education at all.

Researchers have identified many causes contribute to dropping out of school, (Devine, 2006) proposed problems to leave school associated with low educational attainment of parents, the number of family members, and the lack of incentives (Caraway, 2003) that students with low level of education is an important factor leading to high drop-out rates.

And an extension at the level of global efforts, there is a tremendous effort made at the Arab level to confront the dangers of illiteracy because it is a product of many phenomena the most important one of them is dropping out of school.

Dropout is one of the most serious problems faced by the Jordanian educational system in its different stages, the Jordanian legislation confirm the obligatory of education, the ministry of education law number (16) for the year (1964) confirms the obligatory of learning for the two stages of elementary and primary with 9 years of studying (Jaradat 1985 : pages 5) and in the educational development conference which was held in Amman in 1987, extended the primary study to 10 years, from the educational year 1989-1990, the government obliged itself to make learning form the first to tenth grade obligatory (Jaradat, 1990), but it doesn't make any effort to follow any student from this stage who dropout school, only in certain cases, and with personal initiative form some mangers of the directorate of education who observe the management of some schools in the ministry of education, and this leads to the increase of the illiteracy numbers, as a result of the reasons for student's dropping out in various educational stages. it had fallen in some areas, but remained high in other regions, the statistics of the Jordanian Ministry of education indicated that the drop-out rate in Jordan are $(0.75 \%, 0.77 \%$, $0.66 \%)$ for the years $(96 / 97,97 / 98,98 / 99)$ respectively.

Turning to the subject of the current study and the drop-out rates in school districts in the 
governorate of Al Karak it were $(0.62 \%, 0.51 \%, 0.45 \%)$ for the years $(96 / 97,97 / 98,98 / 99)$ respectively. The researchers had statistics from the sections of panning and public education to every school district in the governorate at the beginning of the school year (2012/2013), on the student's numbers of and the student drop-out rates for schools in the Directorate of education districts in general for the past three school years (2009/2010, 2010/2011, $2011 / 2012)$, it was $(0,6 \% 0.52 \%, 0.4 \%)$ respectively, and these are low rates compared with previous years where the drop-out rates for each Directorate separately for these years came as follows: Karak District (0.5\%, 0.4\%, 0.1\%), Mazar district (0.3\% 0.2\%, 0.1\%), Alkaser district (0.5\%, 0.3\%, 0.3\%), southern Jordan Valley School District (1,1\%, 1.2\%, 1.1\%).

The present study came to bridge the deficit resulting from the reduction in the number of studies in Jordan dealing with causes of dropouts among students in different levels of education, and this study came to identify the causes of dropouts among students in school districts in Karak governorate because of the lack of studies on this type.

The researchers want these studies especially in Karak because of their long experience in education, supervision and management in this governorate.

\subsection{The Problem of the Study}

The problem of the study summarized the widespread phenomenon of dropping out of school in many countries of the world at all stages of public education at present time, especially in developing countries, for example, in south-Saharan Africa, , more than 40 million children dropouts in primary school, and will be doubled to 57 million children by 2015 (the British guardian journal translated by Alma'refah magazine, 1999, p. 26), dropout is a global problem, that Jordan suffer from it, causing financial and human waste and is reflected negatively on the educational process the output and have a negative effect in the overall development, and deprived the community of educated human resources that are eligible for community building. In line with the (Obedat, 2003: p. 10) that the problem of the study may be a vague situation or lack of experience and information, or might be a puzzle, and writing the problem as a question is more specific clear and precise, therefore, the problem of the study is summarized in the following question:

What are the causes of dropout of students in general education schools in school districts in Karak governorate from the point of view of school principals and teachers? The following questions are branches of this question:

1) What is the relative importance of each paragraph of the questionnaire the causes of dropout of students from the viewpoint of school principals and teachers in school districts in Karak?

2) What are the relative importance of each of the causes of dropout of students from the viewpoint of school principals and teachers in school districts in Karak?

3) Are there any differences between statically average degrees causes dropout of the students from the viewpoint of school pricnciples and teachers in schools in the school districts in Karak in accordance with Department of education variable? 


\subsection{The Importance of the Study}

a. Primarily The importance of the study is in its attempt to uncover the causes of dropout in the Directorates where dropout is noticed.

b. There is no field study on variables of this study.

c. Show each the schools managements, and parents the reasons for the most important causes of dropout of students from the viewpoint of school principals and teachers in school districts in Karak. For the intensification of efforts to address them, instead of attributing it to any of the reasons leading to it without other causes (social, economic, and psychological).

d. Can be used in subsequent studies.

\subsection{Objectives of the Study}

In the light of the diagnosis of the study problem the study objectives were identified as follows:

1) Identify the relative importance of each paragraph of the questionnaire of the causes of the dropout from the point of view of principals and teachers.

2) Identify the relative importance of each of the causes of the dropout from the point of view of principals and teachers.

3) Identify the cause or causes leading students for dropping out.

4) Getting a clear view of the extent of the problem.

5) Develop possible solutions and measures to reduce the number of drop-outs.

\subsection{The Boundaries of the Study}

1) The study community was identified of the study of principles of public school and teachers in school districts in the governorate of Al Karak (Karak, Mazar, Alkaser, South Jordan). for the academic year 2012/2013.

2) The study tool was questionnaire leading to dropout of students in its four axes (learner, school, family, bad company).

3) Determine the percentage of drop for the following academic year (2009/2010, 2010/2011, 2011/2012).

\section{The Study Terms}

Reasons for dropping out of school: a set of reasons for dropping out of school, either school, family, learner, or bad friends, each factor includes a set of paragraphs about dropping out of school.

Dropping out of school: UNESCO publication difined a school dropout as, a pupil leaves school before the last year of the school stage that he was recorded for. And the Arabic 
Organization for education, culture and science 1973 defined dropout as a form of educational poverty in education, (Abu Hmeidan, 2003). Al-Muhanna (2004) define dropout as a pupils full interruption and leaving school after they have joined it either if that interruption happened directly after joining or after the a class of studying before the completion of the prescribed period for the stage.

Researchers see in their definition to the dropout is: full interruption of the learner educational stage before the completion of the prescribed period for the phase because of external causes and other casus inside the school.

\subsection{General Education: Divided into Two Sections}

a. Basic education: it is a mandatory stage were the student is obliged to finish it freely form first grade to tenth grade ,age (6 to 16 years), according to the regulations and instructions of the Jordanian Ministry of education (Al-bKour, 2003).

b. Secondary education: non-mandatory, two-year study with various educational branches (literary, scientific, vocational, management ...And other).

Principal: is the person primarily responsible for the school administration, provision of appropriate educational environment, and the resident supervisor to ensure that the educational process is working, and coordinates the efforts of workers, guide and evaluate them

Teacher: everybody responsible for the educational process or any specialized educational service in one of the schools of the department of education.

Department of education: is an educational institution under the Ministry of education.

\subsection{Previous Studies}

Khazraji and Samarrai (1993) made the study about the female dropout in the primary stage to identify the causes of dropout from school, develop treatments and solutions to address this problem, and primary school principals, supervisors, and parents of students have answered the study questionnaire. the study was conducted at the country level in the governorates of Baghdad, Nainawa and Basra from 1982/1983 to 1991/1992, the study found the following: Poor awareness of parents of the importance of their daughters completing their primary education, the family need to the girl to work at home, the prevalence of certain values and traditions that prevent girls from going to school in a certain age, some parents do not accept sending their daughters to mixed schools, teachers don't have any interest in female problems.

Study of Obedat (1994) this study aimed to identify the causes of dropout in each of the two stages I and II in the Irbid governorate. The study sample included (175) principals, including (92) male, and (83) female. The study revealed that play friends had a significant impact on the dropout of students in schools, followed by the House, and then the student himself, and finally the school. It also revealed no significant differences between the average degrees of dropout causes of students in each of the first and second stages due to the gender, and type of school variable.

Wendy Schwartz (1995) conducted a study to identify the reasons for students dropping out of 
high school in America as an old problem, and the results indicated that one of these reasons: students having a job with income, family instability, negative self-concept, students do not have control over their lives, obtaining bad grades, students inability to perform home works and lack of harmony with the teachers.

The aim of Al-Sroor study (1997) was to identify the causes affecting the dropout of students in basic education in urban and rural schools in Jordan. The study sample consisted of (1319) individuals. The study indicated that there is a similarity in some causes of dropouts in rural schools and cities which is hating school, being subjected to physical punishment, family pushing their children to leave school, students have a low motivation for learning, teachers not teaching their specialties the number of family members and the small housing. The study also pointed out that there '|is no difference in dropout among rural schools, and cities.

The researcher Lynn Walker (1999) conducted a study intended to: identify key factors in students dropping out from the University of Glasgow, the results indicated that the most important factors in this phenomenon were: family factors, personal factors (weak motivation for learning, low level), factors related to the collage (lack of appropriate activities to such students).

Abdul Rahim, (2000), study on the social and economic factors leading to dropout of basic school pupils, in Shikan in Khartoum, Republic of Sudan, the research use descriptive method in his study, and prepare questionnaire for the purpose of study, sample study consisted of (200 dropout students) (10) students from each school. Where the sample accounted for $15 \%$ of the study population and the results of the study showed that the main reasons for dropping out are: large family size, family income, bad company, in addition to the father absence from home for long hours.

As Al-Bakoor (2003) study came to identify the factors that lead to dropout of students in basic education, in Alghwar southern schools in Jordan from the point of view of principals, teachers and educational workers, a questionnaire of forty-two paragraph was designed including the following factors: educational factors, social factors. The results did not show any statically significant differences in the degree of factors leading to dropout of students according to the respondent's gender (male, female), and the nature of his work (teacher, principal, and mentor) and their interaction with statistical significance.

Al-Robei’ study (2007) talked about the phenomenon of dropping out of primary education, causes, effects and processors, in Iraq after the fall of the previous regime, the researcher used the survey method with the collaboration of UNICEF. The study found the following results: the number of children in the compulsory education age was (86\%), which means that there are (600) children which are not enrolled in school, and that (21\%) Female-school age are not enrolled in school, the study also revealed that the proportion of female-dropping out was (31\%) in the cities, and (51\%) in the rural areas. Dropout is due to: lack of teacher competence and in his relationship with pupils, and unemployment of parents, security at schools, killing teachers and family migration. 


\subsection{Comment on Previous Studies}

Looking at the previous studies that the researchers were able to access, it is clear that results revolve around four basic reasons for dropping out of school:-

1) Personal reasons related to the learner:

Obeidat, 1994; and Wendy Schwartz, 1995; Al - sroor', 1997; Lynn Walker, 1999; Bakoor, 2003; Al-robei', 2007.

2) Reasons related to school:

Obeidat, 1994; Al-sroor', 1997; and Wendy Schwartz, 1995; AL-bakoor, $2003 .$.

3) Reasons related to family:

Khazraji and samarrai, 1993; Obedat, 1994; Wendy Schwartz, 1995; Al-sroor', 1997; Lynn Walker, 1999; Abdul Rahim, 2000; Al-Bakoor, 2003; Al-Robei, 2007.

4) Reasons related to bad companies:

Obeidat, 1994: Abdul Rahim, 2000; Al-Bakoor, 2003.

\section{Study Procedures}

\subsection{Study Community}

The original community consists of all school principals and teachers in school districts in the governorate of Al Karak in the academic year 2012/2013, who is (5406) principal and teacher. (282) principal (5124) teacher spread over four Directorates of education in Karak.

\subsection{Study Sample}

The study sample consisted of (298) principal and teacher. (69) of them are principals and (229) teachers in four Directorates of education in Karak. (27) of them are principals and (75) are teachers in the District of Karak. (18) Principal and (56) teachers in Mazar. (13) Principals and (45) teachers in Alkaser district and (11) Principal and (53) teacher in the southern Jordan Valley. Table(1) shows the study sample.

Table 1: The study sample

\begin{tabular}{cccc}
\hline \multirow{2}{*}{ Directors } & \multicolumn{2}{c}{ study sample } & \multirow{2}{*}{ total } \\
& Principal & Teacher & 102 \\
Karak & 27 & 75 & 74 \\
Mazar & 18 & 56 & 58 \\
Alkaser & 13 & 45 & 64 \\
South Jordan & 11 & 53 & 298 \\
Total & 69 & 229 & \\
\hline
\end{tabular}




\section{Ml Macrothink}

International Journal of Education

ISSN 1948-5476

2013, Vol. 5, No. 2

The current study was limited to school principals and teachers, for several reasons: they are responsible for students in school administratively and educationally, follow up learners' presence and problems between them, and economic and social learners' problems.

\subsection{Tool}

The researchers designed a questionnaire especially for this study using the educational literature and the previous study related to the subject of the research, it was distributed to the sample study, the questionnaire aimed to identify the reasons after dropping out school from the directorate of education in Karak governorate using the views of the principals and teachers about the reasons of students dropping out school in the schools, and they agreed on these four axes : learner, school, family, bad company, and every axis consisted of several paragraphs, the research tool was built on the light of five point Likert scale, where every part of it follow a criteria consisted of five possible answers as follow: 1: 2: 3: 4: 5, considering (5) as very important, (1) as not important, and through these degrees chosen by the members of the sample study the relative importance could be reveled for every paragraph of the questionnaire. And this part of the questionnaire consisted of (37) paragraph, distrusted on axes for the fundamental reasons for dropping out which are: learner reasons, consisted of (10) paragraphs: 1.2.14.15.21.25.26.27.28.32 And school reasons, includes (12) paragraphs: 3.4.6.7.11.16.17.20.22.30.31.37. And family reasons, includes (10) paragraphs: 8.9.10.13.19.24.29.33.34.35. And bad company includes (5) paragraphs: 5.12.18.23.36. Table (2) shows the number of paragraphs, the degree of sharpness, the standard deviation and the weight percentage.

Table 2: The number of paragraphs and the degree of sharpness standard deviation, and percentage weight and degree of importance

\begin{tabular}{|c|c|c|c|c|c|}
\hline Axes & $\begin{array}{l}\text { number the } \\
\text { paragraphs }\end{array}$ & $\begin{array}{l}\text { Degree of } \\
\text { sharpness }\end{array}$ & $\begin{array}{l}\text { standard } \\
\text { deviation }\end{array}$ & $\begin{array}{c}\text { Percentage } \\
\text { weight }\end{array}$ & Evaluation \\
\hline Learner & 10 & 3.09 & 0.96 & 0.62 & $\begin{array}{l}\text { average } \\
\text { importance }\end{array}$ \\
\hline School & 12 & 2.88 & 1.03 & 0.57 & $\begin{array}{l}\text { average } \\
\text { importance }\end{array}$ \\
\hline Family & 10 & 3.10 & 0.92 & 0.62 & $\begin{array}{l}\text { average } \\
\text { importance }\end{array}$ \\
\hline $\begin{array}{l}\text { Bad } \\
\text { company }\end{array}$ & 5 & 4.05 & 0.55 & 0.81 & important \\
\hline Total & 37 & 3.16 & 0.97 & 0.63 & $\begin{array}{l}\text { average } \\
\text { important }\end{array}$ \\
\hline
\end{tabular}

\subsection{Tool Validity}

Questionnaire validity was ensured by showing it to a group of arbitrators from principals teachers, and specialists in psychology, measurement and evaluation, to determine the appropriateness of paragraphs within the reasons for school dropping out, and to find out their views about the clarity of the questionnaire paragraphs, and its appropriateness for sample 
search, arbitrators have confirmed that the questionnaire really measures what it was designed to measure, the researchers took the views of arbitrators, then modified in its light, and reached the final image for it and become ready for implementation, then it was applied to the sample survey other than the research sample from principals and teachers of schools of Karak, where the honesty of the search tool by calculating the square root of the stability factor which was (0.92) and is a high honesty factor.

\subsection{Consistency of the Questionnaire}

Consistency is a good means of testing and is widely used, and it means getting the same results if the questionnaire was redistributed to the sample itself in similar circumstances, and used (re-test), the questionnaire was distributed to a random sample of the study community consisted of (15) principal and (30) teacher, and after (15) days the questionnaire was redistributed to the same sample, and when calculating the correlation coefficient between the two answers it was (0.85) and after correcting the correlation coefficient using (Spearman-Brown) equation its value was (0.92) and this percentage indicates a high stability coefficient between answers.

The distribution and collecting of the questionnaire: after checking consistency and validity of the questionnaire, the questionnaire was distributed to school districts included in the study, the distribution and collecting of the questionnaire took (3) months (400) questionnaire was distributed and (332) retrieve, and there are(34) backup questionnaire that could be excluded in case there is lack of some of the data, then data from the (298)valid questionnaires was entered, and it is a (74.5\%) repeated percentage to the computer for analysis and answering the study questions.

\subsection{Statistical Treatment}

The researchers process the research data and analyzing it statistically, to answer the questions using appropriate statistical processors:

$$
\begin{aligned}
& \frac{\mathrm{F} 1 \times \mathrm{k} 1+\mathrm{f} 2 \times \mathrm{k} 2+\mathrm{f} 3 . .}{\sum \mathrm{K}}=\text { The degree of sharpness } \\
& \frac{\text { The degree of sharpness } \mathrm{x} 100}{\text { Maximum score }}=\text { Weight percentage }
\end{aligned}
$$

- Frequencies, weighted arithmetic means and percentages.

- a standard was determined of the importance degree according to the specific grades for answering categories which was identified mathematically by finding:

Range $=$ maximum value of the answer categories - the smallest value of the answer categories.

Categories length $=$ range $\div$ the number of categories $=4 \div 5=0.80$

Accordingly, judgment on the results will be in the light of the following criteria: the degree is 
from (1-1.80) as unimportant, (1.81-2.60) little important, (2.61-3.39) average important. And (3.40-4.19) is important, and (4.20-5) is very important.

- (Spearman-Brown) Coefficient to measure the validity of the questionnaire.

- Pearson correlation coefficient.

- Test (f) to test the statistical significance differences using (one-way ANOVA), between the independent samples.

\section{Analysis and Discussion of the Results of the Study}

\subsection{The First Question}

What is the relative importance of each paragraph of the questionnaire of the causes of students dropping out of school form the viewpoint of school principals and teachers in school districts in Karak?

Table 3: The degree of sharpness weight, percentage and relative importance of each paragraph of the questionnaire for the reasons of dropping out of school from the viewpoint of school principals in school districts in Karak

\begin{tabular}{|c|c|c|c|c|c|}
\hline $\begin{array}{l}\text { The order } \\
\text { of the } \\
\text { sentences } \\
\text { according } \\
\text { to the tool }\end{array}$ & Paragraphs & $\begin{array}{l}\text { degree of } \\
\text { sharpness }\end{array}$ & $\begin{array}{l}\text { Weight } \\
\text { percentage }\end{array}$ & Evaluation & $\begin{array}{l}\text { The order } \\
\text { of the } \\
\text { sentences } \\
\text { according } \\
\text { to degree of } \\
\text { sharpness }\end{array}$ \\
\hline 1. & $\begin{array}{l}\text { Repeated failure of } \\
\text { the learner }\end{array}$ & 3.25 & 65 & $\begin{array}{l}\text { Average } \\
\text { importance }\end{array}$ & 20 \\
\hline 2. & $\begin{array}{l}\text { the physical } \\
\text { emotional and health } \\
\text { factors of learner }\end{array}$ & 4.42 & 88 & $\begin{array}{l}\text { Very } \\
\text { important }\end{array}$ & 5 \\
\hline 3. & $\begin{array}{l}\text { School is far from } \\
\text { home }\end{array}$ & 1.69 & 34 & Un important & 37 \\
\hline 4. & $\begin{array}{l}\text { weak relationship } \\
\text { between home and } \\
\text { school somewhat } \\
\text { important }\end{array}$ & 2,17 & 54 & $\begin{array}{l}\text { Average } \\
\text { importance }\end{array}$ & 26 \\
\hline 5. & $\begin{array}{l}\text { the learner } \\
\text { accompany some bad } \\
\text { friends }\end{array}$ & 3.91 & 78 & Important & 13 \\
\hline 6. & $\begin{array}{l}\text { teachers don't treated } \\
\text { students well is }\end{array}$ & 4.59 & 92 & $\begin{array}{l}\text { Very } \\
\text { important }\end{array}$ & 2 \\
\hline 7. & $\begin{array}{l}\text { Students are tired of } \\
\text { home works }\end{array}$ & 1.75 & 35 & Un important & 36 \\
\hline 8. & breakdown of family & 3.33 & 67 & Average & 16 \\
\hline
\end{tabular}


average

9. the death of one of the 2.93

parents of learner

10.

the rigid traditions

1.81

1.87

The difficulty to

understand some

subjects less

12.

A learner being a

4.42

friend among learner

who left education

13.

the lack of

3.66

appropriate learner

study atmosphere in

the House is

14.

Learner having a

4.09

physical handicapped

injury that provoke

the mockery of his

colleges

$15 . \quad$ the age of the student

1.85

for the his stage

16. School doesn't do

any recreational and

social activities

17.

18.

19.

20.

21.

22.

23.

24.

Learner subjected to

physical punishment

4.83

friend to learning

assisting family in

2.54

between learners and

4.58

some school mates

the learner

4.11

accompanying failure students in school
Average

23

importance

Little

35

important

Average

importance

88

Very

6

important

Important

14

82

Important

10

37

Little

important

70

Important

15

83

Important

8

97

Very

important

51

Little

important

65

Average

important

92

Very

important

81

Important

11

82

Important

9

parents ignorance of

4.03

81

Important

12 the education value 


\begin{tabular}{|c|c|c|c|c|c|}
\hline 25. & $\begin{array}{l}\text { Learner doesn't have } \\
\text { self-confidence }\end{array}$ & 2.13 & 43 & $\begin{array}{l}\text { Little } \\
\text { important }\end{array}$ & 31 \\
\hline 26. & $\begin{array}{l}\text { Trends and behaviors } \\
\text { of learner }\end{array}$ & 2.32 & 64 & $\begin{array}{l}\text { Little } \\
\text { important }\end{array}$ & 22 \\
\hline 27. & $\begin{array}{l}\text { the learner's needs are } \\
\text { not met within the } \\
\text { school }\end{array}$ & 2.50 & 50 & $\begin{array}{l}\text { Little } \\
\text { important }\end{array}$ & 28 \\
\hline 28. & $\begin{array}{l}\text { difficulty in } \\
\text { understanding some } \\
\text { school subjects } \\
\text { somewhat }\end{array}$ & 3.27 & 65 & $\begin{array}{l}\text { Average } \\
\text { importance }\end{array}$ & 19 \\
\hline 29. & $\begin{array}{l}\text { instability and } \\
\text { frequent movement } \\
\text { of the family }\end{array}$ & 2.28 & 46 & $\begin{array}{l}\text { Little } \\
\text { important }\end{array}$ & 29 \\
\hline 30. & $\begin{array}{l}\text { the lack of guidance } \\
\text { and counseling in } \\
\text { school }\end{array}$ & 2.09 & 42 & $\begin{array}{l}\text { Little } \\
\text { important }\end{array}$ & 32 \\
\hline 31. & $\begin{array}{l}\text { some teachers don't } \\
\text { know the modern }\end{array}$ & 2.78 & 56 & $\begin{array}{l}\text { Average } \\
\text { importance }\end{array}$ & 24 \\
\hline 32. & $\begin{array}{l}\text { ways of teaching } \\
\text { the learner attention } \\
\text { to work after school } \\
\text { at the expense of his } \\
\text { studies }\end{array}$ & 2.87 & 57 & $\begin{array}{l}\text { Average } \\
\text { importance }\end{array}$ & 25 \\
\hline 33. & $\begin{array}{l}\text { the absence of family } \\
\text { follow-up for the } \\
\text { learner academic } \\
\text { level }\end{array}$ & 4.53 & 91 & $\begin{array}{l}\text { Very } \\
\text { important }\end{array}$ & 4 \\
\hline 34. & $\begin{array}{l}\text { the low economic and } \\
\text { cultural level of } \\
\text { family }\end{array}$ & 4.25 & 85 & $\begin{array}{l}\text { Very } \\
\text { important }\end{array}$ & 7 \\
\hline 35. & $\begin{array}{l}\text { insufficient guidance } \\
\text { by parents }\end{array}$ & 1.96 & 39 & $\begin{array}{l}\text { Little } \\
\text { important }\end{array}$ & 17 \\
\hline 36. & $\begin{array}{l}\text { Student dealing with } \\
\text { behaviorally social } \\
\text { deviants }\end{array}$ & 3.29 & 66 & $\begin{array}{l}\text { Average } \\
\text { importance }\end{array}$ & 18 \\
\hline \multirow[t]{2}{*}{37.} & $\begin{array}{l}\text { the weakness of } \\
\text { certain schools } \\
\text { administrations }\end{array}$ & 2.18 & 44 & $\begin{array}{l}\text { Little } \\
\text { important }\end{array}$ & 30 \\
\hline & $\begin{array}{l}\text { The overall average } \\
\text { of the answers }\end{array}$ & 3.18 & 64 & $\begin{array}{l}\text { Average } \\
\text { importance }\end{array}$ & \\
\hline
\end{tabular}

Table (3) of the answers of schools principals shows the most critical and impact paragraphs on the dropout of students, in the first and with a very important evaluation according to the sharpness degree (the friends of the learner are interested in learning, bad-treatment of some 
teachers to learners, learner's inability to adapt within the school, the absence of family follow-up for learner level, physical emotional and health factors of the learner, the learner is among a group of students who left school and the low educational and economic level of the family). It got a sharpness degree (4.83-4.25) and percentage weight (79-85). Paragraphs which got second place and important evaluation according to the sharpness degrees was (the learner subjected to continuous punishment, learner accompanying failure students at school, learner having a physical handicapped that provoke the mockery of his colleagues, the learner fear from some classmates, parents ignorance of the education value, learner accompanying some bad companions, lack of appropriate studying atmosphere in the home, school having no recreational activities or social activities), it got $(4,14,3.48)$ sharpness degree and (83-70) weight percentage. Paragraphs which got third place and average importance according to sharpness degree order (family disintegration such as divorce, inadequate guidance from parents, student dealing with behavioral perverts in the society, difficulty in understanding certain subjects, repeated failure of the learner, the lack of confidence between learners and teachers, learner trends and behaviors, the death of one of the learner parents, some teachers don't know modern methods of teaching, the learner's interest in working after on his studying account and the weak relationship between home and school) it got (3.33. 2.72) sharpness degree and (67-54) weight percentage. Paragraphs which got fourth place and little important evaluation according to arithmetic mean (assisting family in housework, not filling the learner's needs within the school, family instability and frequent travels, the vulnerability of certain schools administrations, the lack self confidence at the learner, the lack of guidance and counseling in school, difficulty of understanding some subjects, age of the pupil for the study phase and rigid social norms) it got (2.54-1.81) sharpness percentage and (51-36) weight percentage. Came in the fifth and last place, and with unimportant evaluation according to the order of arithmetic mean (overwork of learners with homework, school is far from home) it got (1.75-1.69) sharpness percentage and (35-34) weight percentage.

Number18 which reads " learner friends are not interest in education" has got the highest importance (4.83) so it took the first in order, while number (3), which read: "the school is far from home" represented the lowest degree of importance (1.69) and took the last in order, the overall average for the principals responses for the degree of important to (3.18) with (64) weight percentage, and with average importance estimation. 


\section{Macrothink}

International Journal of Education

ISSN 1948-5476

2013, Vol. 5, No. 2

Table 4: The degree of sharpness weight, percentage and relative importance of each paragraph of the questionnaire for the reasons of dropping out of school from the viewpoint of school teachers in school districts in Karak

\begin{tabular}{|c|c|c|c|c|c|}
\hline $\begin{array}{l}\text { The order } \\
\text { of the } \\
\text { sentences } \\
\text { according } \\
\text { to the tool }\end{array}$ & Paragraphs & $\begin{array}{l}\text { Percentage } \\
\text { of sharpness }\end{array}$ & $\begin{array}{c}\text { Weight } \\
\text { percentage }\end{array}$ & evaluation & $\begin{array}{c}\text { The order } \\
\text { of the } \\
\text { sentences } \\
\text { according } \\
\text { to degree } \\
\text { of } \\
\text { sharpness }\end{array}$ \\
\hline 1. & $\begin{array}{l}\text { Repeated failure } \\
\text { of the learner }\end{array}$ & 3.11 & 62 & $\begin{array}{l}\text { average } \\
\text { importance }\end{array}$ & 21 \\
\hline 2. & $\begin{array}{l}\text { the physical } \\
\text { emotional and } \\
\text { health factors of } \\
\text { learner }\end{array}$ & 4.30 & 86 & very important & 7 \\
\hline 3. & $\begin{array}{l}\text { school is far from } \\
\text { home }\end{array}$ & 1.61 & 32 & Un important & 36 \\
\hline 4. & $\begin{array}{l}\text { weak relationship } \\
\text { between home } \\
\text { and school } \\
\text { somewhat } \\
\text { important }\end{array}$ & 2.85 & 57 & $\begin{array}{l}\text { average } \\
\text { importance }\end{array}$ & 23 \\
\hline 5. & $\begin{array}{l}\text { the learner } \\
\text { accompany some } \\
\text { bad friends }\end{array}$ & 3.59 & 72 & important & 14 \\
\hline 6. & $\begin{array}{l}\text { teachers don’t } \\
\text { treated students } \\
\text { well is }\end{array}$ & 4.65 & 93 & very important & 3 \\
\hline 7. & $\begin{array}{l}\text { Students are tired } \\
\text { of home works }\end{array}$ & 1.69 & 34 & unimportant & 35 \\
\hline 8. & $\begin{array}{l}\text { breakdown of } \\
\text { family as divorce } \\
\text { and other average }\end{array}$ & 3.31 & 66 & $\begin{array}{l}\text { average } \\
\text { importance }\end{array}$ & 18 \\
\hline 9. & $\begin{array}{l}\text { the death of one } \\
\text { of the parents of } \\
\text { learner }\end{array}$ & 3.19 & 64 & $\begin{array}{l}\text { average } \\
\text { importance }\end{array}$ & 20 \\
\hline 10. & $\begin{array}{l}\text { the rigid } \\
\text { traditions }\end{array}$ & 1.19 & 24 & Un important & 37 \\
\hline 11. & $\begin{array}{l}\text { The difficulty to } \\
\text { understand some } \\
\text { subjects less }\end{array}$ & 1.79 & 36 & Un important & 33 \\
\hline 12. & a learner being a & 4.40 & 88 & very important & 5 \\
\hline
\end{tabular}


friend among

learner who left

education

13. the lack of

appropriate

learner study

atmosphere in the

House is

14. Learner having a

physical

handicapped

injury that

provoke the

mockery of his

colleges

15. the age of the

35 Un important

student for the his

stage

16. School doesn't do

70 important

any recreational

and social

activities

17. learner subjected

$84 \quad$ very important

8

to physical

punishment

18. lack of attention

from the learners

friend to learning

19. assisting family

in housework

20. the lack of trust

between learners

and some

teachers

21. the learner's

92

55 average

inability to adapt

to the school

22. the learner fear

65

important

from some school

mates

23. the learner

79

average

important

accompanying

failure students in 
school

24. parents ignorance

of the education

value

25. Learner doesn't

42

little important

have

self-confidence

26. trends and

$47 \quad$ little important

behaviors of

learner

27. the learner's

$48 \quad$ little important

needs are not met

within the school

28. difficulty in

67

average

understanding

some school

subjects

somewhat

29. instability and

43 little important

frequent

movement of the

family

30. the lack of

41 little important

guidance and

counseling in

school

31. some teachers

59

average

don't know the

modern ways of

teaching

32. the learner

57

average

attention to work

importance

after school at the

expense of his

studies

33. The absence of

88

very important

6

family follow-up

for the learner

academic level

34. The low

economic and

cultural level of

family 
35

insufficient

guidance by

parents

36

37.

Student dealing
with behaviorally
social deviants
$\begin{aligned} & \text { The weakness of } \\ & \text { certain schools } \\ & \text { administrations }\end{aligned}$
$\begin{aligned} & \text { The overall } \\ & \text { average of the } \\ & \text { answers }\end{aligned}$

1.89

3.39

2.10

3.16
38

68

42

63

Table (4) of the teachers answers shows most critical paragraphs and impact on the dropout of students, the first ranked and with very important evaluation according to the order of paragraphs goes to(injury physical of the learner that provoke mockery of his colleagues, learner's inability to adapt within the school, learner is among group of students who left education, absence of family follow-up for learner level, physical and emotional health factors of the learner, learner subjected to continuous punishment in school) It got (4.88-4.21) sharpness degree and (89-84) weight percentage. Paragraphs which got second place and with important evaluation according to the order of paragraphs (the learner accompany failure students in school, learner fear of some school mates, the low economic and cultural level of the family, parents ignorance of the value of education, the learner accompanying some bad companions, lack of appropriate learning atmosphere for studying at the home, school have no recreational or social activities) it got (3.93-3.50) sharpness degree and (79-55) weight percentage. Paragraphs which got third place and average important evaluation according to the order of paragraphs (learner dealing with perverted behavior student in society, difficulty in understanding some school subjects, family disintegration such as divorce, the lack of confidence between learners and teachers, the death of one of the parents of the student, the student's repeated failure, teachers doesn't know the modern ways of teaching, weak relationship between home and school, the attention of the learner to work at the expense of his learning, helping the family at home chores) it got(3.39-2.76) sharpness degree and(68.55) weight percentage. Paragraphs which got fourth place and little important evaluation according to order of the paragraphs .( Learner need in school are not met, trends and behaviors of learner, family instability and frequent travels, learner have no self-confidence, the vulnerability of certain schools, lack of guidance at school, insufficient guidance by parents) got (2.40-1.89) sharpness degree and (48-38) weight percentage. Came in the fifth and last place, and with unimportant evaluation got(1.79-1.19) sharpness degree and(36-24) weight percentage .

No. 14 which reads " Learner having a physical handicapped injury that provoke the mockery of his colleges" has got the highest importance degree (4.88) and took the first place, number (10), which read: "rigid social traditions" represented the lowest degree of importance (1.19) and came last in the arrangement, the overall average of the school teachers responses to degree 
of importance was (3.16) and (63) weight percentage and with average importance estimation.

Thus, the overall average of sample responses was (3.17) with (63) weight percentage and with average importance estimation.

\subsection{Second Question}

What is the relative importance of each of the causes of students drop out of school from the viewpoint of school principals and teachers in school districts in Karak?

Table 5: The degree of sharpness and weight percentage for each of the reasons for dropping out of school from the viewpoint of school principals and teachers in school districts in Karak

\begin{tabular}{llllll}
\hline \multirow{2}{*}{ No. } & Reasons for & principals $(\mathrm{n}=96)$ & \multicolumn{2}{l}{ school teachers $(\mathrm{n}=229)$} \\
& dropping out of & degree of & weight & degree of & weight \\
& shool & 3.12 & 62.4 & 3.17 & 63.4 \\
\hline 1 & Learner & 2.88 & 57.6 & 2.88 & 57.6 \\
2 & School & 3.13 & 62.6 & 3.09 & 61.8 \\
3 & Family & 4.11 & 82.2 & 4.00 & 80.0 \\
4 & bad companions & 4.11 & percentage & sharpness & percentage \\
\hline
\end{tabular}

It can be seen in the table (5) that the major reasons for dropping out of school from the viewpoint of school principals are: bad companions (82.2\%) respectively followed by: family (62.6\%). learner (62.4\%) school (57.6\%) and that the main reasons for dropping out of school from the viewpoint of school teachers are: bad companions (80.0\%) respectively followed by: the learner (63.4\%). family (61.8\%) and school (57.6\%). as it can be seen from the table that there is agreement on the order of causes for dropping out of school from the viewpoint of principals and teachers, in the first place came bad company, and in last place came school, but the difference was in the second place only (learner), and the third was for the family and they were close to each other.

\subsection{The Results of the Third Question}

Are there statistically function differences between degrees average of reasons for dropping out of school from the viewpoint of principals and teachers in schools in school districts in Karak in accordance with Directorate of education variable (Karak, Mazar, Alkaser, South Jordan)? 
Table 6: The results of one way ANOVA analysis for the reasons of the causes of dropping out of school from the viewpoint of principals and teachers, according to the Directorate of education variable

\begin{tabular}{llccccc}
\hline Reasons & Source of variation & $\begin{array}{c}\text { Square } \\
\text { sums }\end{array}$ & $\begin{array}{c}\text { The } \\
\text { freedom } \\
\text { degree }\end{array}$ & $\begin{array}{c}\text { Average } \\
\text { Squares }\end{array}$ & $\begin{array}{c}\text { F } \\
\text { value }\end{array}$ & $\begin{array}{c}\text { level of } \\
\text { significance }\end{array}$ \\
\hline \multirow{3}{*}{ Learner } & Between groups & 0.047 & 3 & 0.016 & & \\
& Within group & 34.714 & 36 & 0.964 & 0.016 & 0.997 \\
& Total degree & 34.761 & 39 & & & \\
\multirow{5}{*}{ School } & Between groups & 0.082 & 3 & 0.027 & & \multirow{6}{*}{ Family } \\
& Within group & 47.393 & 44 & 1.077 & 0.025 & 0.994 \\
& Total degree & 47.475 & 47 & & & \\
& Between groups & 0.294 & 3 & 0.098 & & \multirow{2}{*}{ Bad } \\
& Within group & 29.799 & 36 & 0.949 & 0.118 & \\
company & Total degree & 30.093 & 39 & & & \multirow{2}{*}{0.787} \\
& Between groups & 0.404 & 3 & 0.135 & & \\
\hline
\end{tabular}

It can be seen in table (6) that there are no statistical differences between average causes for dropping out of school from the viewpoint of principals and teachers at the education directorates (Karak, Mazar, Kaser, southern Jordan Valley) in the governorate of Al Karak.

\section{Discussion of the Study Results}

\subsection{The First Question}

Shown in table no. (3) that the leading paragraphs of the reasons for dropping out school was "the friends of the learner are not interested in learning' with (4.83) sharpness degree, that the learner attracted them by giving them the image that the school had no value or that education worth nothing, and that the workers in workshop such as simple professions earn a lot of money, and that learning took a long time to gain a good material income. This result is consistent with the results of (Obedat, 1994; Alsroor', 1997; Abdul Rahim, 2000) Studies that explains that the play friends had a significant impact on learners dropout of from schools.

It is clear that the main paragraphs for dropping out reasons, was mistreatment of some teachers to the learners which got (4.59) sharpness degrees, displays that learner is subjected to reprimand and insults from teachers in front of his peers in school for not answering the questions directed to him or as a result of a his low grades, failing in some school subjects, neglecting his appearance and forgetting his books or his notebooks which leads to feeling trapped and escape.

It can be seen from table no. (3) the leading paragraphs of the dropout reasons, the learner's inability to adjust to school which obtained (4.58) degree especially with non-social and 
introvert learner who can't adapt with his peers due to some family troubles such as separation of parents, divorce or family atmosphere that is full of quarrels and physical shocks.

The most notable paragraphs which got (4.53) degrees, the absence of family follow-up for learner level, this may be due to the large size of the family, that parents are busy with their works or that they neglect the importance of education, follow-up by parents may be difficult especially for the educational process to figure out the learner point of weakness in school, as well as the lack of communication between parents and the school through the parent counsel which became almost infrequent.

Paragraphs which gained high sharpness degree (4.42), health emotional and physical factors of the learner which prevented him from keeping pace with his colleagues, making him a target of mockery for them, so the school become for him unpleasant experience that makes him seek means by which he tries to prove himself.

Paragraph which got a (4.42) sharpness degree was learner being among friends who left learning because they make him feel the tendency to leave education, and that school doesn't satisfy his perverted wishes, so he drop out of school in order to satisfy these desires thinking that the environment outside the school will satisfy his ambition.

Paragraph which got (4.25) degree ,low economic and cultural level of the family, and represent a high estimate is important, this paragraph is represented in a low standard of living of the family, the need of the learner family to work to contribute in supporting the family, and the inability of the family to meet the needs of the learner, school fees and clothing, and the paragraph is also due to lack of interest by families of learner to education which is higher illiteracy among parents and that they are not convinced of the usefulness of education.

Then came the following paragraphs with important estimation which is represented in the following order according to the degree of sharpness (4.14-3.48), (learner continuously subjected to punishment, the learner accompanying failed at school, learner having a physical handicapped that provoke the mockery of his colleagues, the learner fear from some classmates, parents doesn't value education, learner is a friend of bad company, there is no good studying environment at home, weak relation between school and home) Followed by the following paragraphs with average importance and came according to the paragraphs with(3.33-2.72) sharpness degree, (family disintegration as divorce, insufficient guidance by parents, student dealing with social behavioral pervert in the society, difficulty in understanding certain subjects, the repeated failure of the learner, the lack of confidence between learners and teachers, learner trends and behaviors, the death of one of the parents of learner, some teachers don't know the modern methods of teaching, the learner's interest in working after school in the account of his studying, weak relationship between home and school). With the estimation of school principals the following paragraphs came with little importance and(2.54-1.81) sharpness degree, (assisting family in housework, not satisfying the learner's needs within the school, family instability and frequent travels, the vulnerability of certain schools, learner have no self-confidence, lack of guidance in school, difficulty in understanding some subjects, age of the pupil for the stage, ridge social traditions), paragraphs which ranked last and is considered un important according to principals point of 
view in learners dropping out from school according to the sharpness degree (1.75-1.69), (educated feeling tired form homework, school far home), homework from the viewpoint of school principle was not a reason for dropping out school ,as modern education undertaken the responsibility of taking care of schoolwork, so it will not be a burden on learners, by giving automatic homework by the teacher without taking interest in rephrasing it according to the needs and requirement of the student, or not following the homework after ward and grading it, guiding student using it in the class, learner facing a family or personal problems such as being busy with family needs or not having a suitable family circumstances to do his homework for school and the inconvenience caused by the brothers, the length of the homework in terms of quantity, difficultly, length, routine or importance of it`. For the school being far from home it was not a reason for dropping out as their school in every village and suburb and there are good transportation between home and school.

Shown in table no. (4) that the leading paragraphs of the reasons for school dropping out is the physical injured of the learner that provoke the mockery of his colleagues which got (4.88) degree, as a result of the learner physical diseases to some senses such as hearing and vision which affects the student's abilities in comprehension, assimilation and follow the instructor in the class and the health problem may appear as a result of a speech and pronunciation diseases threatening the student for ridicule by his colleagues or makes him withdrawing from his relations with others and this will be displayed in his academic achievement, that leads him to escape from the school to avoid this ironic and mocking situation.

It is clear that the clearest paragraphs of the reasons for dropping out, that is in accordance with what the school principals see in the following paragraphs which got in order (4.69-4.30) as a sharpness degree, (the learner friends are not interested in education, bad-treatment of some teachers to learners, learner's inability to adapt within the school, the absence of family follow-up for learner level, physical and emotional health factors of the learner), this is a proof that the study sample is in direct contact with the learner and knowledge of its problems.

It also can be seen from table no. (4) which the leading paragraph of dropping out, the learner continuously subjected to punishment which got (4.21) degrees, because some teachers exceed discipline order, and shows his desire for domination, the frustrated teacher look for a victim to put on him his ill deep desires and frustrated aspirations, and no better than a student to exercise this venting, arguing that the learner is weak learner, so he subjected the learner to punishment, and the only way to escape from this punishment is to dropout from school.

One of the important paragraphs which got an important evaluation of teachers ' in order according to(3.93-3.50) sharpness degrees (the learner accompany students failure students at school, the learner fear from some classmates, low economic and cultural level of the family, the ignorance of the parents of the education value, lack of appropriate studying atmosphere at home, school doesn't have any recreational activities and social activities), there have been highly similarity between principals and teachers ' estimations. The following paragraphs followed by with average importance evaluation and came in order with (3.39-2.76) sharpness degree, (students dealing with socially behavioral pervert, difficulty in understanding some subjects, family disintegration such as divorce and others, lack of trust 
between learners and some teachers, the death of one of the student parents, the student's repeated failure, failure of some teachers in using the modern ways of teaching, weak relationship between home and school, the attention of the learner to work at the expense of his studying, helping the family). In the estimation of school teachers came the following paragraphs with a little importance evaluation (2.40-1.89) sharpness degree, (not fill fulling the learner's needs within the school, orientations and behaviors of learner, family instability and frequent travels, learners having no self-confidence, the weakness of certain schools adminstrations, lack of guidance at school, insufficient guidance by parents), paragraphs ranked last according to the view point of school teachers in as non important according to sharpness degree (1.79-1.19), (difficult to understand some Course materials, student life for the his studying stage, learner feeling tired of homework, the school is far from home, the ridged traditions).

It is clear from the paragraphs that learners feeling tired of homework, school far from home came last according to the view point of principals and it was commented on previously, but a rigid social traditions, came last place from the point of view of a school teachers and with less important evolution from the point of view of principals, it is highlighted through some customs and traditions which develop the wrong trends towards learning particularly family relations, disharmony among family members, frequent quarreling between the mother and father and the cruelty used by some parents toward their children, all lead to the pupil hate of the school and eventually leaving it. The paragraph of rigged customs and traditions was incompatible with the study of (Al-khazraji and Samarrai, 1993) which considers the prevalence of certain values and traditions that prevent girls from going to school at a certain age, and rejecting the mixing of gender in school, the most paragraphs of dropping out of school. In all came the results of the first question degrees from the point of view of each of the principals and teachers in education directorates in the Karak governorate to average importance estimate.

\subsection{Second Question}

Shown in table no. (5) that the major reasons for dropping out of school from the viewpoint of school principals in school districts in the governorate of Al Karak, are respectively: bad company, family, student, school. But from the viewpoint of teachers are respectively: bad company, learner, family, school. reasons between principals and teachers in the first place are the same, bad company, and came last school, the difference occurred in family where it came second place in principals point of view, and third in teachers point of view, the fact that the learner came in second place in teachers point of view as teacher are in direct contact with the learners, and by directly interacting with them inside the class room which is more than it with the principals, the principals ' results came in agreement with results of a Obedat (1994) study where it indicates that playmate have a significant impact in students dropping out for schools, followed by the family, then the learner, and finally the school.

It can be seen from the table that school principals and teachers put a major responsibility on the bad guys for the learners escape from school, as it received the highest sharpness degree and percentage from the viewpoint of principles and teachers, while the rest of the reasons 
that they put no major responsibility on the learners dropping out school. And they obtain a close sharpness degree and weight percentage, it doesn't not have a strong reason for dropping out of school, compared with bad companions which have (4.11) sharpness degree (82,2\%) weight percentage from the point of view of principals, and (4.00) sharpness degree and $(80,0 \%)$ weight percentage from the viewpoint of teachers.

The researchers attribute to the bad guys a significant impact on the school drop-out, where we find that they lure the learners in various to leave school, including: a stroll in the gardens, and hanging around on the streets, or practice certain bad behaviors such as theft, and what help in get behind bad friends is the lack of adequate control, whether from official society administrations, or of the family, and families don't give their children appropriate opportunities to practice some recreational activities at appropriate times and under their supervision (Al-hoot, 1980:P.107).

\subsection{The Third Question}

Shown in table no. (6) that there are no statistically differences between average degrees of the reasons causing the dropout from the viewpoint of school principals and teachers in school districts in Karak in accordance with variable Directorate of education (Karak, Mazar, Alkaser, southern Jordan Valley).

The researchers attributed the similarity in educational and social conditions, from educational terms the same curricula are distributed to all directorates, and the same textbooks are used without any changed. it was one Directorate, and not long ago was separated to those departments, with continuous movements between managers and teachers between these directorates it is similar in social conditions and close in their customs and traditions. Noting that the drop-out rates are in decline than in previous years and referring to the introduction of the research, we found that there is difference in dropout rates in some departments, the introduction of the study pointed to the school drop-out rates in school districts in the governorate of Al Karak which was obtained by researchers from the statistics departments Planning and public education at the level of each district alone in Karak in the beginning of the school year (2012/2013), for the past three school years (2009/2010, 2010/2011, 2011/2012), it was (0,6\% 0.52\%, 0.4\%) respectively, and these are low rates compared with previous years, the drop-out rates came as follows: Karak District $(0.5 \%$, $0.4 \%, 0.1 \%)$, Mazare district (0.3\% 0.2\%, 0.1\%), Alkaser district (0.5\%, 0.3\%, 0.3\%), South Jordan Valley School District $(1,1 \%, 1.2 \%, 1.1 \%)$. the high drop-out rate in the southern Jordan Valley School District is clear, and this is consistent with the study of albacore (2003) which revealed the impact of economic, social and cultural factors and outcomes in the dropping out in the southern Jordan Valley District and comparing them with other directorates, and indicated that the greatest impact was in the low standard of living of the family, and the need of the learner to contribute with the work to support the family, in the absence of scientific qualifications of the parents to work, So most of them are forced to work in agriculture in certain seasons, leading to the increase of the number of absent days of the learner, and the low level of educational attainment compared to his colleagues leading eventually to drop out school. 


\section{Recommendations}

1) Fortifying family education by parents to the learners, and raise their awareness degree particularly with regard to their future, and the importance of science, and continuously pushing them to hung up to science with continuous follow-up for their school.

2) Having controlling laws not strict laws in schools that stand in the way of learners who want to escape school and prevent them from continuing on this path.

3) Continus update and development of educational curricula and using teaching methods to remove routine and boredom from them.

4) Creating recreational programs to the learners ease the pressure of studying and to be an outlet to energize their lives and raise their morale.

5) Following school mutual respect approach between learners one hand and the school staff on the other hand, and not allowing the insulting of teachers under any circumstances, and when there is a need for punishment there are other methods that are effective and non-offensive

6) Inform parents about their child's friends, to learn who are bad friends from them and push their children to stay away from them using guidance.

7) Paying attention to the psychological state of the learners, and here come the role of educational and psychological instructor in schools, where students can go to when there is a problem for help before it gets worse.

8) Making further studies to determine the causes of dropouts among learners at various levels and in various school districts.

\section{References}

Abu Hmeidan, Y. (2003). Behavior modification theory and practice. Amman, Almada House for publishing and distributing.

Abdul Rahim, I. (2000). Socio-economic factors leading to primary stage pupils dropping out in Shikan governorate, unpublished MS, Omdurman Islamic University.

Al-bkoor, R. (2003). Factors that lead to dropout of students in basic education in southern Aghwar schools from the viewpoint of principals, teachers and educational workers. Master thesis, University of El Fasher, the Sudanese Republic.

Al -Hoot, A. (1980). Study on Libyan youth, and some social problems. Faculty of education, University of alfateh, Tripoli.

Al-Khazraji, K., \& Alsamri, M. (1993). Female students dropout at primary level, methods and treatments. Baghdad: Ministry of education, Centre for educational research and studies in cooperation with the United Nations Children's Fund (UNICEF). 
Al-Muhanna, I. (2001). School dropping out factors in deviants, King Fahd national library under publishing.

Al-Rubaie, M. (2007). The phenomenon of dropping out of primary education causes, effects and treatments. A search with the help of the United Nations for Children's Fund (UNICEF).

Al-Sroor, N. (1997). Causes of dropout of students in both urban and rural schools. Magazine studies, University of Jordan, 24(1), 174-144.

Caraway, K., \& Tucker, C. (2003). Self efficacy, goal orientation and fear of failure as Predictors of School engagement in High School Students. Psychology in The School, 40, 417 - 427. http://dx.doi.org/10.1002/pits.10092

David, S., \& Amy, S. (2006). High- stakes Testing and Dropout Rates. Retrieved from http//web.gc.cuny.edu./humanties

Department of strdan. (1982). Annual bulletin of statistics. 33, 15.

Jaradat, E., \& Abdel Nabi, A. (1990). Prospects for World Education (education for all). Teacher's litter, 31(3), 12-17.

Jaradat, E., \& Balla, V. (1985). Curriculum and the needs of the Arab community. Teacher's litter, 27(3), 3.

Lynn, W. (1999). Longitudinal Study of Drop-out and Continuing Students Who Attended the Pre-University Summer School at the University of Glasgow. International Journal of Lifelong Education, 18(3), 217-233. http://dx.doi.org/10.1080/026013799293801

Obeidat, S. (1993). Causes of dropout of students in the basic stage in Irbid governorate from the point of view of male and female principals. Jordan University studies, 21(4), 70 $-39$.

Obeidat, T. (2003). The fundamentals of scientific research. Issue 8, Wael publishing, Jordan, Amman.

The British newspaper the guardian "translation of Alma'refah magazine". (1999). 20 million children read literacy, Saudian Alma'refah magazine, of the Ministry of education, Riyadh, 56, $27-25$.

Wendy, S. (1995). School Dropouts: New Information about an Old Problem, ERSC/CAE Digest,Number 10.0 ERIC clearinghouse on urban Education New York NY - USA.

\section{Copyright Disclaimer}

Copyright reserved by the author(s).

This article is an open-access article distributed under the terms and conditions of the Creative Commons Attribution license (http://creativecommons.org/licenses/by/3.0/). 